\title{
An exploratory study of recovery of rare-earth elements from monazite in mild conditions using statistical-mixture design
}

\author{
A.C.S.P. Souza ${ }^{1}$, E.C. Giese ${ }^{1, *}$ \\ ${ }^{1}$ Center for Mineral Technology (CETEM), Av. Pedro Calmon 900, CEP 21941 908, Rio de Janeiro, Brazil \\ *Corresponding author Email: egiese@cetem.gov.br ; ellengiese@gmail.com \\ DOI: https://doi.org/10.34256/irjmt2124 \\ Received: 05-03-2021, Accepted: 08-03-2021, Published: 10-03-2021
}

Abstract: Monazite is a phosphate mineral, considered an essential source of light rare-earth elements (REE). The present work sought to evaluate different methods of solubilization of REE through the use of different concentrations of inorganic acids $\left(\mathrm{H}_{2} \mathrm{SO}_{4}, \mathrm{HCl}\right.$, and $\left.\mathrm{HNO}_{3}\right)$ and organic acids (citric, oxalic, and lactic) in mild conditions at room temperature. According to the results, the inorganic acid solutions favored the solubilization in order of $\mathrm{Ce}^{3+}, \mathrm{La}^{3+}, \mathrm{Nd}^{3+}, \mathrm{Pr}^{3+}$, and $\mathrm{Sm}^{3+}$ elements, while organic acid solutions only favored the solubilization of $\mathrm{Ce}^{3+}$ and $\mathrm{La}^{3+}$. Nitric acid was the more efficient leaching agent for the first group. In the case of organic acids, lactic acid solubilized $\mathrm{Ce}^{3+}$, while mixtures of lactic and citric acids appeared to solubilize $\mathrm{La}^{3+}$.

Keywords: Monazite, Rare-Earth elements, Chemical leaching, Design of Experiments.

\section{Introduction}

Monazite is an orthophosphate with a predominance of light rare-earth elements (REE). Monazite has a chemical formula (Ce, La, Nd, Th) $\mathrm{O}_{4}$, containing approximately $70 \%$ of rare-earth oxides (REO). Radioactive elements, about $0.1-30 \%$ thorium (Th) and up to $1.5 \%$ uranium (U), can be found in its composition, responsible for imparting electrical, magnetic, and catalytic properties to some REO. In addition to these elements, moderate amounts of iron $(\mathrm{Fe})$, aluminum (Al), calcium (Ca), magnesium $(\mathrm{Mg})$, silica $(\mathrm{Si})$, titanium $(\mathrm{Ti})$, and zirconium $(\mathrm{Zr})$ can be found in monazite also [1].

Lanthanides or REE can be classified into (i) light (57-60): lanthanum (La), cerium (Ce), praseodymium ( $\mathrm{Pr}$ ) and neodymium (Nd); (ii) medium (61-64): promethium (Pm), samarium (Sm), europium (Eu) and gadolinium (Gd); (iii) heavy (65-71): terbium $(\mathrm{Tb})$, dysprosium (Dy), holmium (Ho), erbium (Er), thulium $(\mathrm{Tm})$, ytterbium $(\mathrm{Yb})$ and lutetium (Lu). Currently, REE is increasingly used in industries related to green energy, as for hybrid cars, electric motors, and wind turbines [2].

The first mineral containing REE to be explored industrially was the monazite. Its name is derived from the Greek monazein, which means "to be alone," observed for its characteristics of crystals granted and for being quite rare during its discovery, giving an allusion to the rarity of the mineral [3]. In physical processing, heavy minerals concentration comes from various methods, involving density, electrostatic and magnetic separations, depending on the mineralogical assembly of the minerals to be used [4]. Monazite is predominantly a by-product of sand mining with heavy minerals, from where $\mathrm{Ti}$ and $\mathrm{Zr}$ minerals are also commonly explored.

The acid leaching process is a technique that aims at solubilizing metals using an acid, which can be under constant agitation and controlled temperature. During the process, a substance that is sought to be obtained is extracted from a solid matrix through its dissolution by a leaching agent, selectively chosen according to its ability to dissolve the metal [5]. According to Kim \& Osseo-Asare [6], monazite undergoes physical processing first, followed by chemical processing, which can occur through acid treatment using sulfuric acid. The sulfate $\left(\mathrm{SO}_{4}{ }^{2-}\right)$ ion of sulfuric acid can act as a ligand which reacts with REE as follows [7]:

$2 \mathrm{REEPO}_{4}(\mathrm{~s})+3 \mathrm{H}_{2} \mathrm{SO}_{4}=(\mathrm{REE})_{2}\left(\mathrm{SO}_{4}\right)_{3}(\mathrm{~s})+6 \mathrm{H}^{+}+2 \mathrm{PO}_{4}^{-3}$

In the last decade, several studies have been published addressing the interactions between microorganisms and minerals carrying REE, including the solubilization of REE from definite matrices through 
reactions with microbial metabolites [8] and immobilization of REE of liquid matrices, mainly by sorption by biomass [9-13].

The microbially mediated REE solubilization occurs mainly via acidolysis, oxidoreduction, and complexation reactions. Acidolysis, that is, the protoninduced metal ion solubilization implies the exchange and replacement of metallic elements from mineral surfaces by protons. The REE mobilization through reducing or oxidative reactions or through the action of metabolically produced complexing agents has also been described in the literature [14].

Biohydrometallurgy can be considered an emerging green technology for the recovery of metals due to its environmentally friendly, simple, and economical processing. Bioleaching consists of a hydrometallurgical process of dissolving minerals through a group of microorganisms capable of producing acids and or oxidizing agents from the constituents of the ore itself in the leaching process [15]. However, few studies seek to elucidate the biological advantage of the interaction between microorganisms and minerals with REE $[16,17]$.

Few researchers have studied the assistance of microbial organic acid producers in the monazite bioleaching process. Thus, the present work sought to evaluate different leaching agents for REE extraction from a Brazilian monazite sample using a mixturedesign experiment.

\section{Experimental}

Analytical grade reagents were used in preparing acid concentrations of $100 \mathrm{~g} \mathrm{~L}^{-1}$. These acids were used in chemical leaching tests that mimicked metal dissolution achieved by microorganisms under mild temperature conditions. For monazite leaching tests, about $0.5 \mathrm{~g}$ of monazite sample was added in $150 \mathrm{~mL}$ Becker glass containing $50 \mathrm{~mL}$ of different acid mixtures.

The effect of the mixture of two sets containing three different inorganics $\left(\mathrm{H}_{2} \mathrm{SO}_{4}, \mathrm{HCl}, \mathrm{HNO}_{3}\right)$ (Table 1) or organics (citric, oxalic, lactic) (Table 2) acids on the solubilization of REE from Brazilian monazite was evaluated through a statistical mixture-design.

The experimental runs remained on a shaking table, at room temperature, under constant agitation of $100 \mathrm{rpm}$ over 60 minutes. After the end of the stirring, $20 \mathrm{~mL}$ of the leachate was centrifuged at $4000 \mathrm{rpm}$ and $25{ }^{\circ} \mathrm{C}$ for 15 minutes, and the supernatant was collected for analysis. Determination of the final concentration of metal ions in solution was performed by inductively-coupled plasma atomic emission spectrometry (ICP-OES Perkin Elmer, OPTIMA3000, USA).

Table 1. Statistical mixture-design matrix defining conditions for inorganic leaching of Brazilian monazite.

\begin{tabular}{|c|c|c|c|c|c|c|c|c|}
\hline \multirow[t]{2}{*}{ Run } & $\mathrm{H}_{2} \mathrm{SO}_{4}$ & $\mathrm{HCl}$ & $\mathrm{HNO}_{3}$ & $\mathrm{Ce}$ & La & Nd & $\mathrm{Pr}$ & $\mathrm{Sm}$ \\
\hline & $\left(x_{1}\right)$ & $\left(x_{2}\right)$ & $\left(x_{3}\right)$ & $\left(\mathrm{Y}_{1}\right)$ & $\left(\mathrm{Y}_{2}\right)$ & $\left(\mathbf{Y}_{3}\right)$ & $\left(\mathbf{Y}_{4}\right)$ & $\left(Y_{5}\right)$ \\
\hline 1 & 0 & 0 & 1 & 1.03 & 0.52 & 0.39 & 0.11 & 0.09 \\
\hline 2 & 1 & 0 & 0 & 2.58 & 1.21 & 0.96 & 0.26 & 0.19 \\
\hline 3 & 0 & 1 & 0 & 3.63 & 2.00 & 1.37 & 0.37 & 0.26 \\
\hline 4 & 0.5 & 0 & 0.5 & 1.00 & 0.48 & 0.39 & 0.10 & 0.08 \\
\hline 5 & 0.5 & 0.5 & 0 & 3.13 & 1.61 & 1.17 & 0.31 & 0.22 \\
\hline 6 & 0 & 0.5 & 0.5 & 1.07 & 0.67 & 0.42 & 0.11 & 0.09 \\
\hline 7 & 0.33 & 0.33 & 0.33 & 1.22 & 0.69 & 0.46 & 0.12 & 0.11 \\
\hline
\end{tabular}

Table 2. Statistical mixture-design matrix defining conditions for organic leaching of Brazilian monazite.

\begin{tabular}{ccccccccc}
\hline Run & Citric & Oxalic & Lactic & Ce & La & Nd & Pr & Sm \\
\cline { 2 - 7 } & $\left(\mathbf{x}_{4}\right)$ & $\left(\mathbf{x}_{5}\right)$ & $\left(\mathbf{x}_{6}\right)$ & $\left(\mathbf{Y}_{6}\right)$ & $\left(\mathbf{Y}_{7}\right)$ & $\left(\mathbf{Y}_{8}\right)$ & $\left(\mathbf{Y}_{9}\right)$ & $\left(\mathbf{Y}_{10}\right)$ \\
\hline 1 & 0 & 0 & 1 & 0.15 & 0.09 & N.D. & N.D. & N.D. \\
2 & 1 & 0 & 0 & 0.06 & 0.06 & N.D. & N.D. & N.D. \\
3 & 0 & 1 & 0 & 0.19 & 0.10 & N.D. & N.D. & N.D. \\
4 & 0.5 & 0 & 0.5 & 0.04 & 0.04 & N.D. & N.D. & N.D. \\
5 & 0.5 & 0.5 & 0 & 0.03 & 0.04 & N.D. & N.D. & N.D. \\
6 & 0 & 0.5 & 0.5 & 0.16 & 0.09 & N.D. & N.D. & N.D. \\
7 & 0.33 & 0.33 & 0.33 & 0.02 & 0.03 & N.D. & N.D. & N.D. \\
\hline
\end{tabular}

N.D., not detected.

In a mixture experiment, the sum of the component fractions must be equal to unity, and their proportions must be non-negative. The restrictions on the levels of each factor are expressed as follows:

$$
\sum_{i=1}^{q} x_{i}=1(\text { i.e. }, 100 \%)
$$

$x_{i}$ represents the proportion of the $i^{\text {th }}$ component in the mixture, and $q$ is the number of components. The independent variables in the mixture experiments for optimization of REE extraction ( $\mathrm{Y}, \mathrm{mg}$ $\left.\mathrm{L}^{-1}\right)$ were: inorganic acid leaching set: $\mathrm{x}_{1}\left(\mathrm{H}_{2} \mathrm{SO}_{4}, \mathrm{~mL}\right)$, $\mathrm{x}_{2}(\mathrm{HCl}, \mathrm{mL})$, and $\mathrm{x}_{3}\left(\mathrm{HNO}_{3}, \mathrm{~mL}\right)$; and organic acid leaching set: $x_{1}$ (citric, $m L$ ), $x_{2}$ (oxalic, $m L$ ), and $x_{3}$ (lactic, $\mathrm{mL}$ ).

Analysis of variance (ANOVA) and multiple regression analyses was performed using Statistica version 13.5 (StatSoft, Inc.). 


\section{Results and Discussion}

The use of statistical methodologies such as response surface methodology (RSM) and BoxBehnken to optimize monazite ore leaching has been reported in the literature [18]. In the present work, a statistical mixture-design technique was used to study the effects of different inorganic and organic acids and their mixtures on the REE extraction from Brazilian monazite, as described in Table 1 and Table 2. An equation was obtained for the inorganic acid leaching $\left(\mathrm{H}_{2} \mathrm{SO}_{4}, \mathrm{HCl}, \mathrm{HNO}_{3}\right)$ of $\mathrm{Ce}^{3+}\left(\mathrm{Y}_{1}\right.$, Equation 2), $\mathrm{La}^{3+}\left(\mathrm{Y}_{2}\right.$, Equation 3), $\mathrm{Nd}^{3+}\left(\mathrm{Y}_{3}\right.$, Equation 4), $\mathrm{Pr}^{3+}\left(\mathrm{Y}_{4}\right.$, Equation 5) and $\mathrm{Sm}^{3+}\left(Y_{5}\right.$, Equation 6$)$ through the analysis of the multiple regressions of the experimental data:

$$
\begin{aligned}
& Y_{1}=3.218095 x_{3} \\
& Y_{2}=1.807048 x_{3} \\
& Y_{3}=1.215810 x_{3} \\
& Y_{4}=0.325143 x_{3} \\
& Y_{5}=0.232571 x_{3}
\end{aligned}
$$

Effect terms of the variable $\mathrm{x}_{1}$ (sulfuric acid) and $\mathrm{x}_{2}$ (chloridric acid) were discarded as nonsignificant, as shown in the variance analysis (ANOVA). According to Figure 1, the solubilization of REE had increased following the REE molecular weight, and the order of REE extractions was $\mathrm{Ce}^{3+}>\mathrm{La}^{3+}>\mathrm{Nd}^{3+}>\mathrm{Pr}^{3+}$ $>\mathrm{Sm}^{3+}$.
To date, sulfuric acid is the primary acid that has been used industrially for extracting REE from monazite. However, different researchers used nitric acid to dissolve monazite and other associated metals from apatites (phosphorites) containing monazite [19]. Apparently, nitric acid is more effective for leaching REE from phosphorites than sulfuric acid [20]. Monazite from East Siberia, e.g., containing 3-7\% REO, was leached in $\mathrm{HNO}_{3}$ [21].

Organic acids have been studied as alternative leaching reagents for REE extraction from REE-bearing ores to address those issues and provide environmentally acceptable techniques. The organic acid is an alternative chemical to replace the strong acid in the leaching process. This is because the organic acid has a low level of a hazard than the strong acid [22]. The dissolution of minerals by organic acid weathering is usually explained based on surface reaction models in which the dissolution rate is positively correlated with the concentration of protonated, deprotonated, and organic complexes on the surface of the solid phase [23]. Metabolic products from the growth of Aspergillus terreus and Paecilomyces spp. Fungal strains have leached REE from monazite to concentrations 1.7-3.8 times those of $\mathrm{HCl}$ solutions. Organic acids released by these microorganisms included acetic, citric, gluconic, itaconic, oxalic, and succinic acids [16].

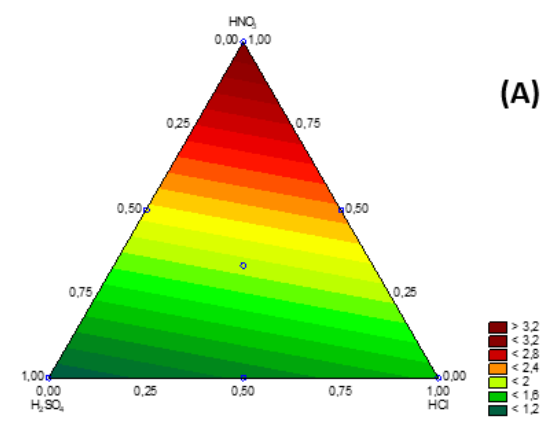

(A)
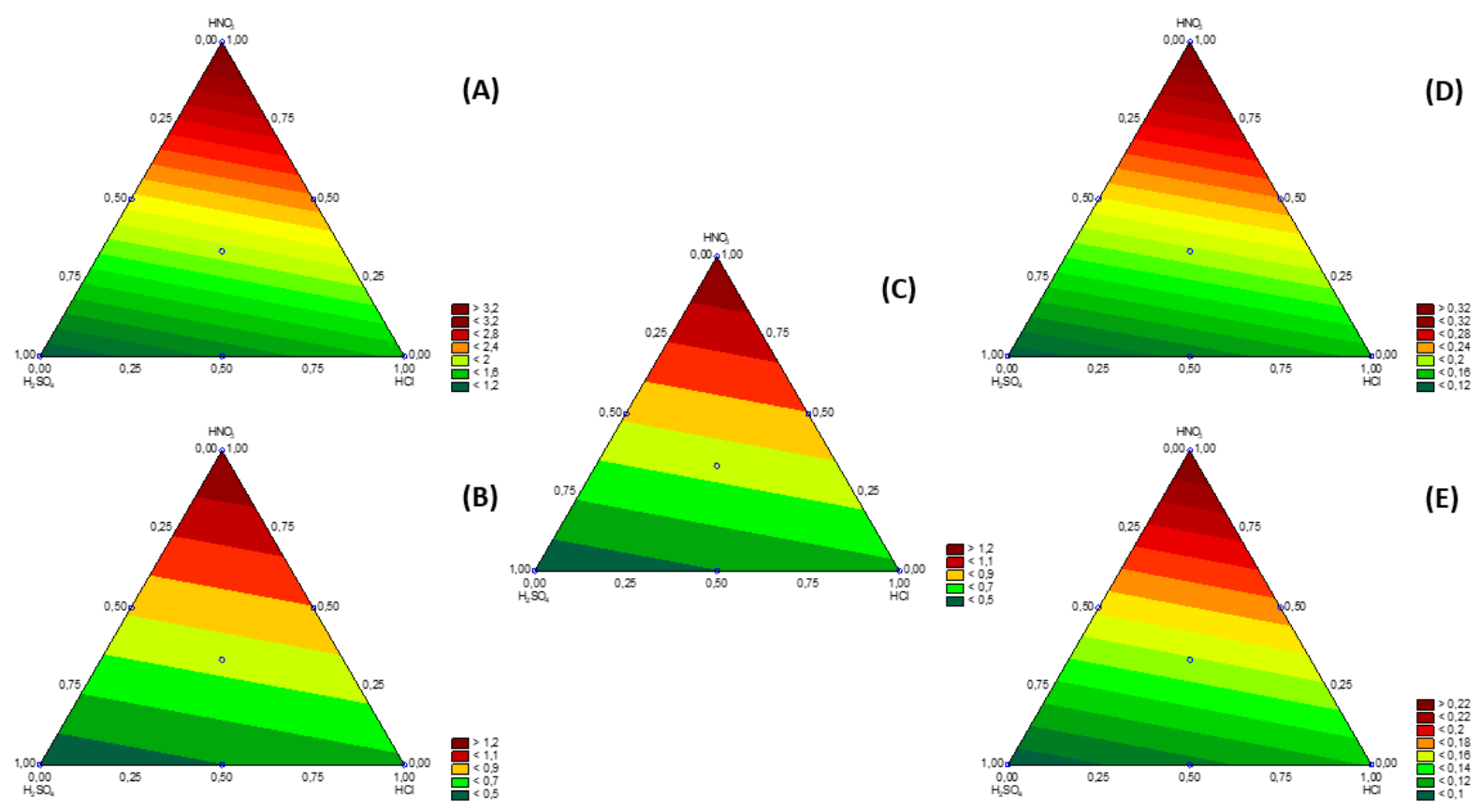

Figure 1. Response surface contours for chemical leaching of Brazilian monazite by inorganic acid leaching. (A) $\mathrm{Ce}^{3+}$ extraction (mg L-1); (B) La ${ }^{3+}$ extraction $\left(\mathrm{mg} \mathrm{L}^{-1}\right)$; (C) $\mathrm{Nd}^{3+}$ extraction $\left(\mathrm{mg} \mathrm{L}^{-1}\right)$; (D) $\mathrm{Pr}^{3+}$ extraction $\left(\mathrm{mg} \mathrm{L}^{-1}\right)$ and (E) $\mathrm{Sm}^{3+}$ extraction $\left(\mathrm{mg} \mathrm{L}^{-1}\right)$. 

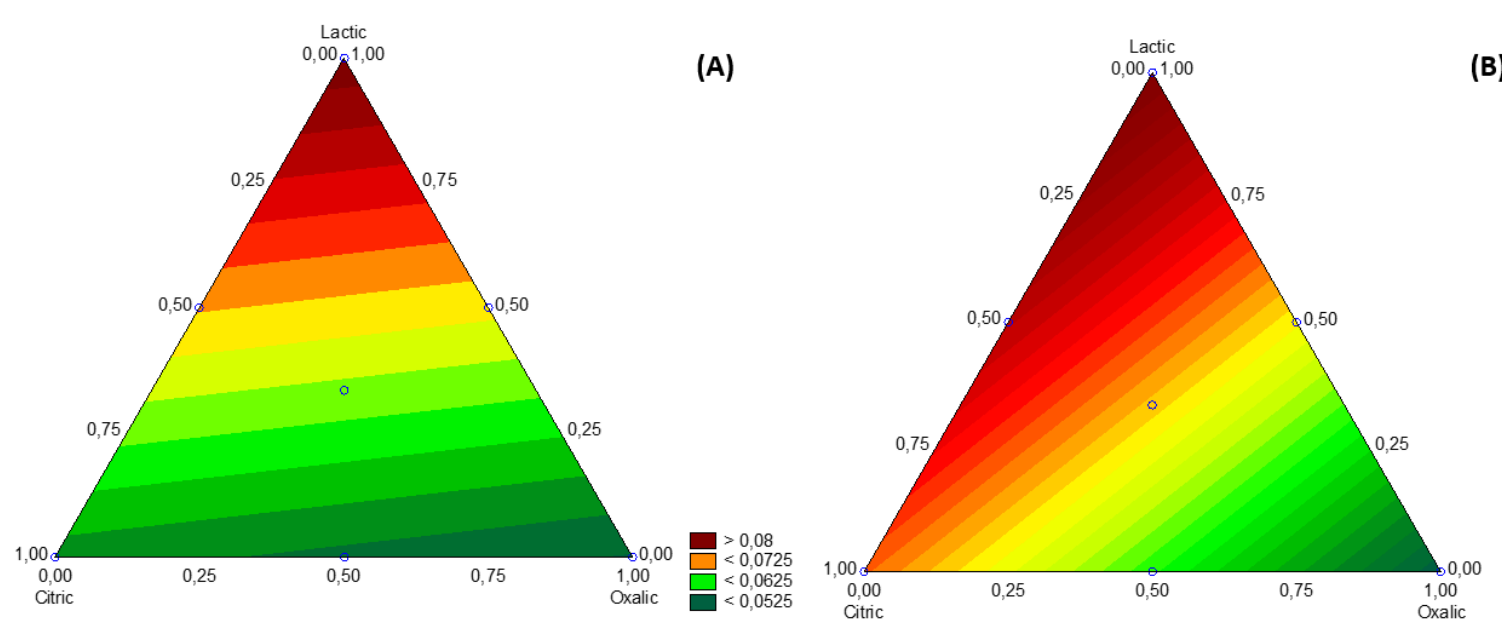

(B)

Figure 2. Response surface contours for chemical leaching of Brazilian monazite by organic acid leaching. (A) $\mathrm{Ce}^{3+}$ extraction $\left(\mathrm{mg} \mathrm{L}^{-1}\right)$ and $(\mathrm{B}) \mathrm{La}^{3+}$ extraction $\left(\mathrm{mg} \mathrm{L}^{-1}\right)$

An equation was obtained for the organic acid leaching (citric, oxalic, lactic) of $\mathrm{Ce}^{3+}\left(\mathrm{Y}_{6}\right.$, Equation 7) and $\mathrm{La}^{3+}\left(\mathrm{Y}_{7}\right.$, Equation 8) through the analysis of the multiple regressions of the experimental data:

$$
\begin{aligned}
& Y_{6}=0.084286 x_{3} \\
& Y_{7}=0.033238 x_{3}
\end{aligned}
$$

Effect terms of the variables $x_{1}$ (citric acid) and $x_{2}$ (oxalic acid) were discarded as non-significant, as shown in the variance analysis (ANOVA). According to Figure 2, REE's solubilization has increased following the REE molecular weight, and the order of REE extractions was $\mathrm{Ce}^{3+}>\mathrm{La}^{3+}$.

No contents of $\mathrm{Nd}^{3+}, \mathrm{Pr}^{3+}$, and $\mathrm{Sm}^{3+}$ were detected in the leachates. Greater than $40 \%$ solubilization of $\mathrm{Ce}^{3+}$ and $\mathrm{La}^{3+}$ was obtained by Lazo et al. [24] from an oxalic acid leaching following EDTA precipitation. Analysis of the solids determined that the REE were re-precipitating as oxalate salts [25]. Also, according to Figure 2, lactic acid was able to solubilize $\mathrm{Ce}^{3+}$ (Figure 2A) while mixtures of lactic and citric acid seemed to be able to solubilize $\mathrm{La}^{3+}$ (Figure 2B). The order of strength of studied acids is oxalic $\left(\mathrm{pK}_{\mathrm{a}}=1.25\right)$ $>$ citric $\left(\mathrm{pK}_{\mathrm{a}}=3.13\right)>$ lactic $(\mathrm{pKa}=3.83)$.

Lactic acid is an $\alpha$-hydroxy acid and contains a carboxyl group adjacent to a hydroxyl group. The presence of an a-hydroxyl group increases the acidity compared with that of an average monobasic acid. Lactic acid leaching systems have been employed successfully in sustainable REE recovery from monazite [26]. In addition to reducing $\mathrm{pH}$, which somewhat increases phosphate minerals' solubility, some organic acids can form complexes with the cations released from phosphate minerals and thus improve overall solubilization.

\section{Conclusion}

The ongoing development of new advanced technologies created increasing demands for REE in the international markets, emphasizing new resources to ensure adequate supply and access. This preliminary study indicated that the mechanism of acid leaching of Brazilian monazite depends on the acid used, possibly the solubilization of $\mathrm{Ce}^{3+}$ and $\mathrm{La}^{3+}$ under organic acid leaching conditions. These studies are essential to developing bioleaching process methods for a sustainable REE extraction.

\section{References}

[1] C.K. Gupta, \& N. Krishnamurthy, Extractive metallurgy of rare earths. International Material $\begin{array}{llll}\text { Reviews, } & 37 & \text { (1992) } & \text { 197-248. }\end{array}$ https://doi.org/10.1179/imr.1992.37.1.197

[2] A.C.S.P. Souza, M. Nascimento, E.C. Giese, Desafios para a extração sustentável de minérios portadores de terras raras, Holos, 1 (2019) 1-9. https://doi.org/10.15628/holos.2019.8274

[3] J.H.L. Voncken, (2016) The ore minerals and major ore deposits of the Rare Earths. In: Voncken, J.H.L. (Ed) The Rare Earth Elements. Springer, Singapore.

[4] K. Kwanho, J. Soobok, Separation of monazite from placer deposit by magnetic separation, 
Minerals, $\quad 9 \quad$ (2019)

https://doi.org/10.3390/min9030149

[5] F. Sadri, F. Rashchi, \& A. Amini, Hydrometallurgical digestion and leaching of Iranian monazite concentrate containing rare earth elements Th, Ce, La and Nd, International Journal of Mineral Processing, 159 (2017) 7-15. https://doi.org/10.1016/i.minpro.2016.12.003

[6] E. Kim, \& K. Osseo-Asare, Aqueous stability of thorium and rare earth metals in monazite hydrometallurgy: Eh-pH diagrams for the systems Th-, Ce-, La-, Nd- $\left(\mathrm{PO}_{4}\right)-\left(\mathrm{SO}_{4}\right)-\mathrm{H}_{2} \mathrm{O}$ at $25^{\circ} \mathrm{C}$, Hydrometallurgy, 113-114 (2012) 67-78. https://doi.org/10.1016/j.hydromet.2011.12.007

[7] R. Panda, A. Kumari, M.K. Jha, J. Hait, V. Kumar, J. Rajesh Kumar, \& J.Y. Lee, Leaching of rare earth metals (REMs) from Korean monazite concentrate, Journal of Industrial and Engineering Chemistry, $20 \quad$ (2014) 2035-2042. https://doi.org/10.1016/i.jiec.2013.09.028

[8] L. Zhang, H. Dong, L. Yan, L. Bian, X. Wang, Z. Zhou, \& Y. Huang, Bioleaching of rare earth elements from bastnaesite-bearing rock by actinobacteria, Chemical Geology, 483 (2018) 544557.

https://doi.org/10.1016/i.chemgeo.2018.03.023

[9] N.V. Coimbra, M. Nascimento, \& E.C. Giese, Avaliação do uso de biomassa bacteriana imobilizada na biossorção de terras-raras leves e médias, Holos, 6 (2017) 136-146. https://doi.org/10.15628/holos.2017.6445

[10] G.P. Heidelmann, T.M. Roldão, S.G. Egler, M. Nascimento, \& E.C. Giese, Uso de biomassa de microalga para biossorção de lantanídeos, Holos, 6 (2017)

170-179.

https://doi.org/0.15628/holos.2017.6436

[11]E.C. Giese, A.M. Barbosa-Dekker, \& R.F.H. Dekker, Biosorption of lanthanum and samarium by viable and autoclaved mycelium of Botryosphaeria rhodina MAMB-05, Biotechnology Progress, (2019) e2783. https://doi.org/10.1002/btpr.2783

[12]E.C. Giese, \& C.S. Jordão, Biosorption of lanthanum and samarium by chemically modified Bacillus subtilis free cells, Applied Water Science, 9 (2019) 182. https://doi.org/10.1007/s13201-019$\underline{1052-3}$

[13]E.C. Giese, Biosorption as a green technology for the recovery and separation of rare earth elements, World Journal of Microbiology and Biotechnology, 36 (2020) 52. https://doi.org/10.1007/s11274-020$\underline{02821-6}$
[14] H. Fathollahzadeh, T. Becker, J.J. Eksteen, A.H. Kaksonen, \& E.L.J. Watkin, Microbial contact enhances the bioleaching of rare earth elements, Bioresource Technology Reports, 3 (2018) 102108. https://doi.org/10.1016/j.biteb.2018.07.004

[15]E.C. Giese, Biolixiviação: Uma avaliação das inovações tecnológicas na biomineração de minerais sulfetados no período de 1991 a 2015, Tecnologia em Metalurgia, Materiais e Mineração, 14 (2017) 192-203. http://dx.doi.org/10.4322/2176$\underline{1523.1205}$

[16] V.L. Brisson, \& W.-Q. Zhuang, \& L. Alvarez-Cohen, Bioleaching of rare earth elements from monazite sand, Biotechnology and Bioengineering, 113 (2015) 339-348. https://doi.org/10.1002/bit.25823

[17]Y. Qu, \& B. Lian, Bioleaching of rare earth and radioactive elements from red mud using Penicillium tricolor RM-10. Bioresource Technology, 136, (2013) 16-23. https://doi.org/10.1016/..biortech.2013.03.070

[18]T. Qiu, H. Yan, J. Li, Q. Liu, \& G. Ai, Response surface method for optimization of leaching of a low-grade ionic rare earth ore. Powder Technology, 330 330-338. https://doi.org/10.1016/i.powtec.2018.02.044

[19]A. Kumari, R. Panda, M. Kumar Jha, R. Kumar, J.Y. Lee, Process development to recover rare earth metals from monazite mineral: A review, Minerals Engineering, 79 (2015) 102-115. http://dx.doi.org/10.1016/j.mineng.2015.05.003

[20]F.T. Bunus, \& R. Dumitrescu, Simultaneous extraction of rare earth elements and uranium from phosphoric acid, Hydrometallurgy, 28 (1992) 331338. https://doi.org/10.1016/0304-386X(92)90038-2

[21]V.I. Kuzmin, G.L. Pashkov, V.G. Lomaev, E.N. Voskresenskaya \& V.N. Kuzmina, Combined approaches for comprehensive processing of rare earth metal ores, Hydrometallurgy, 129-130 (2012). 1-6. https://doi.org/10.1016/i.hydromet.2012.06.011

[22] C.P. Faizul, C. Abdullah, \& B. Fazlul, Review of extraction of silica from agricultural wastes using acid leaching treatment, Advanced Materials Research, $626 \quad$ (2012) 997-1000. https://doi.org/10.4028/www.scientific.net/AMR.626 $\underline{.997}$

[23]G. Furrer, \& W. Stumm, The role of surface coordination in the dissolution of $\delta-\mathrm{Al}_{2} \mathrm{O}_{3}$ in dilute acids, Chimia, 37 (1983) 338-341.

[24]D.E. Lazo, L.G. Dyer, R.D. Alorro \& R. Browner, Treatment of monazite by organic acids I: Solution conversion of rare earths, Hydrometallurgy, 174 
(2017) 202-209.

https://doi.org/10.1016/j.hydromet.2017.10.003

[25]D.E. Lazo, L.G. Dyer, R.D. Alorro \& R. Browner, Treatment of monazite by organic acids II: Rare earth dissolution and recovery, Hydrometallurgy, 179 (2018) 94-99. https://doi.org/10.1016/i.hydromet.2018.05.022

[26]D.E. Lazo, L.G. Dyer, R.D. Alorro \& R. Browner, Observations of the varied reactivity of xenotime and monazite in multiple systems, Minerals $\begin{array}{llll}\text { Engineering, } & 159 & \text { (2020) } & 106633 .\end{array}$ https://doi.org/10.1016/j.mineng.2020.106633

Acknowledgement

A.C.S.P. Souza is grateful for the scientific initiation scholarship granted by CNPq/PIBIC/CETEM

Author's contribution

Ana Carolina S. P. de Souza carried out the experiments. Ellen C. Giese conceived the original idea, supervised the project and wrote the manuscript.

\section{Conflict of interest}

The authors have no conflicts of interest to declare that they are relevant to the content of this article.

\section{Funding}

No funding was received for conducting this study.

\section{About the License}

(C) The author(s) 2021. The text of this article is open access and licensed under a Creative Commons Attribution 4.0 International License

\section{Cite this Article}

A.C.S.P. Souza, E.C. Giese, An exploratory study of recovery of rare-earth elements from monazite in mild conditions using statistical-mixture design, International Research Journal of Multidisciplinary Technovation, Vol 3, Iss 2 (2021) 20-25. DOI: https://doi.org/10.34256/irimt2124 